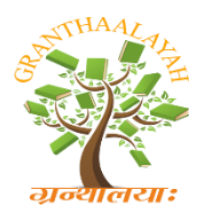

INTERNATIONAL JOURNAL OF RESEARCH GRANTHAALAYAH

A knowledge Repository

Social

\title{
INFLUENCE OF PARENTING STYLES ON THE ACADEMIC PERFORMANCE OF SECONDARY SCHOOL STUDENTS IN NIGER STATE
}

\author{
Ogunsola `Femi *1 \\ ${ }^{* 1}$ Federal University of Technology Minna, Niger State. Nigeria
}

\begin{abstract}
The study examined the effects of parenting styles on the academic performance of secondary school students in Niger state, using the Ex - Post Facto design. Two hypotheses were formulated. Sample for the study were 600 SS 2 students randomly selected from 30 secondary schools within the state, using a researcher developed Parenting Style Questionnaire (PSQ) and Standardised Students Continuous Assessment Scores (SCAS) in English and Mathematics. Data was analysed using a One - Way Analysis of Variance (ANOVA). Results showed that neither parenting styles nor parenting styles of supervision of children`s schoolwork have significant effect on students' academic performance. These findings are an indication of the apparent less commitment of parents in their parenting roles. It was recommended that guidance and counselling seminars should be organised for parents on effective parenting skills.
\end{abstract}

Keywords: Parenting Styles; Academic Performance; Secondary School Students.

Cite This Article: Ogunsola `Femi. (2018). "INFLUENCE OF PARENTING STYLES ON THE ACADEMIC PERFORMANCE OF SECONDARY SCHOOL STUDENTS IN NIGER STATE." International Journal of Research - Granthaalayah, 6(10), 65-70. https://doi.org/10.29121/granthaalayah.v6.i10.2018.1162.

\section{Introduction}

Nigeria is a complex society due to the impact of the Western world`s technology impinging on families. Access to televisions and internet communication services has provided youths with an unprecedented means of socialisation and gathering of useful information necessary for improving their academic performance, if responsibly utilised and supervised by parents. That is modernisation has made parenting more challenging. Parenting is a child rearing endeavour which DiGiulio (2000) acknowledged as being an onerous and challenging task. It demands parental love, care, control, supervision and commitment to children`s upbringing. Psychologists like Jeynes, (2003) and Barimund (1991), adduced that parenting styles help to shape children`s social competence. 
There are different types of parenting styles. The autocratic parenting style involves the use of rigid control, strict and punitive standards. Children brought up under this type of parenting style tend to be dependent, unsocial, rebellious and withdrawn as well as have poor academic performance, (Eze, 2006). Democratic parenting style involves rearing children under moderate parental control, love, warm acceptance and respect for children`s feelings. Democratic parents also accord their children the opportunity to dialogue and reason with them. Children in this type of situation tend to be independent, friendly and of high self - esteem. Academically, they perform better than children of autocratic parenting.

Laissez - faire parenting style involves lax parenting control, care and inconsistent use of principles such that children are free to take decisions for themselves. Children of laissez - faire parenting tend to have care free attitude and insubordinate behaviours. Academically they tend to perform lower than the children of autocratic and democratic parenting styles. (Garg, Levin, Urajnik, \& Kauppi, (2005), Barimund, 1991). Studies (Kordi, A \& Baharudin, (2010); Mensah, \& Kuranchie, (2013) have shown that psychological autonomy and parental involvement in the supervision of children`s school work affect academic performance. Children of democratic parenting whose parents were warm and accepting often were seen to engage in socially acceptable behaviours and perform academically better than children of laissez - faire parenting whose parents were rejecting and uninvolving in the supervision of their children`s school work.

Iheanacho (2000) noted that love is a parenting factor which is requisite for good mental health and achievement of better academic performance. When parenting is autocratic, children become intimidated and inactive. Consequently, they perform poorly academically. Similarly, Eze (2006) noted that when parent - child relationship is strained conflicts often arise between the two and the children's academic performance drop. It is common Knowledge that the harsh socio economic imperatives this present time have negatively affected the parenting roles of many parents. The poor economic conditions have forced couples into engaging in all types of paid jobs or self - employed businesses which take them away from their homes for many hours, thus abandoning their children to the whims and caprices of nannies and house helps.

The unmonitored adolescents pre - occupy themselves with watching of videos and internet films, all at the expense of their studies. This apparent uncomplimentary parenting demeanour cannot be overlooked because it has not only negatively affected parenting roles but has also been linked to the generally observed poor academic performance of students in examinations. (Oloyede \& Demide (2013); Oloyede, (2010); Kalgo, (2002). According to Tay \& Tam (2011) poor academic performance should be strongly rejected because it brings untold hardships and frustration on an individual and backwardness to the development of a nation.

Therefore, this present study investigated the effects of parenting styles on the academic performance of secondary school students in Niger state, for this purpose two null hypotheses were formulated:

1) Parenting styles do not have significant effect on academic performance of secondary school students.

2) There is no significant effect of parenting styles of supervision of children`s school work on the academic performance of secondary school students. 


\section{Methodology}

Ex - post Facto survey design was adopted for this study because the subjects of study had already been parented in their various homes. The sample for the study was 600 (300 males and 300 females) Senior Secondary school two (SSS2) students randomly selected from a population of all Senior Secondary school two (SSS2) students in Niger state, Nigeria. A researcher - constructed 36 items 4 - scale, Likert type, Parenting Style Questionnaire (PSQ) and Students Continuous Assessment Scores (SCAS) in English Language and Mathematics were used for data collection. The two subjects were used because they were the two major compulsory subjects for the students'. The PSQ was face and item validated by two guidance counsellors. A pilot test was also conducted to determine the reliability coefficient which was calculated as 0.88 .

The year 2014 SCAS records in Mathematics and English Language were used to assess the students' performance. The scores were transformed to standard $t-$ scores. This helped to ensure that all possible school and teacher factor induced errors were reasonably reduced, thus ensuring the validity of the scores. The PSQ was personally administered by the researcher while the class teachers assisted the researcher in collecting the SCAS records in both subjects. Data was analysed using One Way Analysis of Variance (ANOVA) at 0.05 level of significance.

\section{Results}

Hypothesis one (Ho1): Parenting styles do not have significant effect on the academic performance of secondary school students.

Table 1: Anova Summary of The Effect of Parenting Styles on Students`Academic Performance.

\begin{tabular}{|l|l|l|l|l|}
\hline Group & Parenting style & $\mathbf{N}$ & $\overline{\boldsymbol{X}}$ & Sd \\
\hline 1. & Laissez - Faire & 97 & 52.14 & 11.62 \\
\hline 2. & Democratic & 286 & 81.43 & 10.79 \\
\hline 3. & Autocratic & 217 & 52.06 & 11.36 \\
\hline
\end{tabular}

\begin{tabular}{|l|l|l|l|l|l|}
\hline Variable & Source of variable & Ss & Df & Ms & F \\
\hline Academic & Between groups & 247.64 & 2 & 123.82 & 0.96 \\
Performance & Within groups & 77012.20 & 597 & 129.00 & \\
Total & & 77259.84 & 599 & & \\
\hline
\end{tabular}

Critical $\mathrm{F}=3.02, \mathrm{df}=2$ and $597, \mathrm{P}>.05$

Table 1 shows democratic parenting styles $(n=286)$ as the predominant parenting style among the students. This is followed by autocratic parenting style $(\mathrm{n}=217)$ while the least declared parenting style among the students is laissez - faire $(n=97)$. The ANOVA results show a calculated $\mathrm{F}-$ value of 0.96 which is less than the critical $\mathrm{F}$ - value of 3.02 at $\mathrm{P}>.05$, $\mathrm{df}=2$ and 597 . Hence, the null hypothesis is accepted. This implies that there is no significant effect of parenting styles on the academic performance of the secondary school students in Niger state. The observed differences in their academic performances are due to other factors than parenting styles.

Hypothesis 2 (Ho2): There is no significant effect of parenting styles of supervision of children`s school work on academic performance of secondary school students. 
Table 2: Anova Summary of The Effect of Parenting Styles on Supervision of Children 'S School Work on Academic Performance.

\begin{tabular}{|l|l|l|l|l|}
\hline Parenting style & Group & $\mathbf{N}$ & $\overline{\boldsymbol{X}}$ & Sd \\
\hline Laissez - Faire & 1.Low Supervision & 47 & 53.64 & 13.42 \\
\hline Democratic & 2.Moderate Supervision & 152 & 51.78 & 10.19 \\
\hline Autocratic & 3.High Supervision & 401 & 51.98 & 11.53 \\
Total & & 600 & 52.06 & 11.36 \\
\hline
\end{tabular}

\begin{tabular}{|l|l|l|l|l|l|}
\hline Variable & Source of variable & Ss & Df & Ms & F \\
\hline Academic & Between groups & 131.31 & 2 & 65.66 & 0.05 \\
Performance & Within groups & 77128.52 & 597 & 129.19 & \\
Total & & 77259.83 & 599 & & \\
\hline
\end{tabular}

Critical $\mathrm{F}=3.02, \mathrm{df}=2$ and $597, \mathrm{P}>.05$

Table 2 presents the group sizes, means, standard deviations and $\mathrm{F}$ - value of the one way ANOVA of the effects of parenting styles of supervision of children's school work on academic performance. Results of the analyses show children under high supervision of autocratic parents as being highest in number $(n=401)$ while those under moderate (democratic) supervision are $n$ $=152$ and those under low supervision of laissez - faire parents as being lowest $(n=47)$. The calculated F- value of 0.05 is insignificant when compared with the critical $F$ - value of 3.02 at $P$ $>.05$, df $=2$ and 597. Hence the hypothesis is retained, Thus, parenting styles in terms of supervision of children`s school work do not significantly affect academic performance of students.

\section{Discussion}

The results of the first null hypothesis show that parenting styles do not have significant effect on the students' academic performance. This finding is supported by earlier findings that factors other than parenting styles also affect students' academic performance. (Turner,Chandler, \& Heffer, (2009); Eze, (2006). Naturally human beings are born with varying genetic potentials which the home, school and society help to shape and develop. The insignificant effect of parenting styles on the academic performance of students in this study is indicative of the apparently observed tendency of less parental care and attention to children by a good number of Nigerian parents, who are often pre - occupied themselves with their personal pursuits. The fact that this finding is at variance with some earlier studies (Patock-Peckham, \& Morgan-Lopez, (2006); Kalgo, 2002); Barimund, (1991) suggest that parents need to impact their children`s academic performance positively.

The results of the second hypothesis also reflect that parenting styles in terms of supervision of children`s school work do not significantly affect academic performance of students. This finding implies that some other extraneous variables are also impacting on the students academic performance. More parental commitment to the supervision of children's`school work is necessary for parenting styles to have effect on the student's academic performance. Parents should enhance their children`s academic performance by positively reinforcing them and providing their basic needs and educational materials. (Turner, Chandler, \& Heffer, R. W. (2009).; Jeup,(2008). The finding that as large as 401 students were being parented under high autocratic supervision out of 
a total sample of 600 students is a cause for concern. Autocratic style of supervision needs to be de - emphasised as studies have shown children of such parenting tend to be dependent, timid, aggressive and academically lower than those children parented under democratic parenting style. (Akhtar, Z. (2012); Kalgo, (2002).

\section{Conclusions}

From the findings of this study, it can be concluded that parenting styles and parenting styles of supervision do not have significant effect on secondary school students' academic performance in Nigeria.

\section{Recommendations}

Based on the conclusions from this study, the following recommendations were made:

- Parents should be more democratic than autocratic or laissez - faire in their parenting.

- Parents should be firm in authority and committed to the provision of their children`s needs.

- Parents should keenly supervise their children's academic work.

- Guidance and Counselling seminars and workshops should be regularly organised for parents and teachers on effective parenting methods.

\section{References}

[1] Akhtar, Z. (2012). The effect of parenting style of parents on the attachment styles of undergraduate students. www.languageinindia.com. Retrieved on 15th October, 2012.

[2] Baumrind, D. (1991). The influence of parenting style on adolescent competence and substance use. Journal of Early Adolescence, 11(1), 56-95.

[3] Eze, J. U. (2006) Effects of Parenting styles on the academic performance of secondary shool studernts in Cross River State. Journal of Education Improvement vol. 3 pp. 24 - 31.

[4] Garg, R., Levin, E., Urajnik, D. and Kauppi, C. (2005). Parenting styles and academic achievement for East Indian and Canadian adolescents. Journal of Comparative Family Studies, 36(4), 653-662.

[5] Kalgo, F.A. (2002) Parenting styles and learning achievement of Nigerian children: A study of Usman Dan Fodio University Staff primary School Pupils. Journal of Nigerian Society for Education Psychologists. 1 (1) 56 - 65.

[6] Kordi, A \& Baharudin, R. (2010) Parenting Attitude and Style and Its Effect on Children's School Achievements. International Journal of Psychological Studies Vol. 2, No. 2 pp. 217 - 222.

[7] Jeup, A. (2008). The Relationship between Parenting and Academic Achievement. [Online] Available: http://www.usfcollab.usf.edu/researchdetails.cfm?researchID=197 (May 1st, 2010)

[8] Jeynes, W. (2003). A Meta-Analysis: The Effects of Parental Involvement on Minority Children's Academic Achievement. Education \& Urban Society, 35 (2), 202-218.

[9] Mensah, M. K \& Kuranchie, A. (2013) Influence of Parenting Styles on the Social Development of Children. Academic Journal of Interdisciplinary Studies MCSER Publishing, Rome-Italy Vol. 2 No 3. Pp.123 - 129

[10] Oloyede, O. I. (2010) Levels of acquisition of science process skills among year two secondary school chemistry students. UNISWA Research Journal of Agric. Science and Technology. Vol. 13 (1) $14-19$.

[11] Oloyede, O. I. \& Demide, C. O. (2013) Effect of previous knowledge on students Cognition in some content areas in chemistry. Eurasian Journal of Physics and Chemistry. Vol. 5 (1) 71 - 79. 
[12] Patock-Peckham, J. A., \& Morgan-Lopez, A. A. (2006). College drinking behaviors: mediational links between parenting styles, impulse control, and alcohol-related outcomes. Psychology of Addictive Behaviors, 20, 2, 117-125.

[13] Pong, S.L., Hao, L., \& Gardner, E. (2005). The roles of parenting styles and social capital in the school performance of immigrant Asian and Hispanic adolescents. Social Science Quarterly, 86, 928-950.

[14] Tay, E. L. and Tam, C. L. (2011). Relationship between perceived parenting styles and coping capability among Malaysian secondary school students. Proceedings of International Conference on Social Science and Humanity, 2, $20-23$.

[15] Turner, E. A., Chandler, M. and Heffer, R. W. (2009). Influence of parenting styles, achievement motivation, and self-efficacy on academic performance in college students. Journal of College Student Development, 50(3), 337-346

\footnotetext{
*Corresponding author.

E-mail address: ogunsoladrfemi@ gmail.com
} 